\title{
Physiological Characteristics and Anti-obesity Effect of Lactobacillus plantarum Q180 Isolated from Feces
}

\author{
Sun-Young Park ${ }^{1,2}$, Seong-A Cho', Sae-Hun Kim², and Sang-Dong Lim ${ }^{1 *}$ \\ ${ }^{1}$ Korea Food Research Institute, Seongnam 463-746, Korea \\ ${ }^{2}$ Department of Food Bioscience and Technology, Korea University, Seoul 136-701, Korea
}

\begin{abstract}
Obesity is strongly associated with several metabolic and chronic diseases and has become a major public health problem of worldwide concern. This study aimed to investigate the physiological characteristics and anti-obesity effects of Lactobacillus plantarum Q180. Lactobacillus plantarum Q180 was isolated from the faces of healthy adults and found to have a lipase inhibitory activity of $83.61 \pm 2.32 \%$ and inhibited adipocyte differentiation of 3T3-L1 cells $(14.63 \pm 1.37 \%)$ at a concentration of $100 \mu \mathrm{g} / \mathrm{mL}$. The strain was investigated for its physiological characteristics. The optimum growth temperature of L. plantarum Q180 was $37^{\circ} \mathrm{C}$. Lactobacillus plantarum Q180 showed higher sensitivity to novobiocin in a comparison of fifteen different antibiotics and showed the highest resistance to rifampicin, polymyxin B and vancomycin. The strain showed higher $\beta$-galactosidase and $\mathrm{N}$-acetyl- $\beta$-glucosaminidase activities. It also did not produce carcinogenic enzymes such as $\beta$-glucuronidase. The survival rate of $L$. plantarum Q180 in MRS broth containing $0.3 \%$ bile was $97.8 \%$. Moreover, the strain showed a $97.2 \%$ survival rate after incubation for $3 \mathrm{~h}$ in $\mathrm{pH} 2.0$. Lactobacillus plantarum Q180 was displayed resistance to Escherichia coli, Salmonella Typhimurium and Staphylococcus aureus with rates of 55.6\%, 38.0\% and 47.6\%, respectively. These results demonstrate that $L$. plantarum Q180 has potential as a probiotic with anti-obesity effects.
\end{abstract}

Keywords: Lactobacillus plantarum, physiological characteristics, anti-lipase activity, anti-adipogenic activity

\section{Introduction}

Obesity, a condition in which an abnormally large amount of fat is stored in adipose tissue, causing an increase in body weight, has become a major public health concern worldwide. It is now generally acknowledged that obesity results from an imbalance between energy intake and consumption (Wood et al., 1998), and that this condition is strongly associated with several metabolic and chronic diseases including heart disease, cancer, obstructive sleep apnea, arthritis, hypertension, hyperlipidemia, and type 2 diabetes associated with insulin resistance (Wickelgren, 1998). To date, pharmacological treatments have not appeared to be effective in promoting continuous long-term weight loss (Glenny et al., 1997). Therefore, further research is needed to discover new drug therapies that can be used to reduce the prevalence of obesity.

Probiotics are defined as viable microbial dietary sup-

*Corresponding author: Sang-Dong Lim, Korea Food Research Institute, Seongnam 463-746, Korea, Tel: +82-31-780-9082, Fax: +82-31-780-9160, E-mail: limsd@kfri.re.kr plements that have various beneficial effects on a host's health. These effects include, among others, the amelioration of hypercholesterolemia (Park et al., 2007) and hypertension (Aihara et al., 2005); the prevention of cancer (Rafter et al., 2004); and modulation of the immune system (Baken et al., 2006). In addition, recent experimental studies have demonstrated the preventive effects of some bacterial strains on obesity. L. curvatus HY7601 and $L$. plantarum KY1032 have been reported to reduce adipogenesis in 3T3-L1 cells (Park et al., 2011). According to Moon et al. (2012), when the lactic acid bacterial (LAB) strain Weissella koreensis OK1-6 isolated from kimchi is used to treat differentiating pre-adipocyte 3T3-L1 cells, the cells accumulate significantly less intracellular lipid.

A potentially probiotic strain is expected to have several desirable properties in order to exert its beneficial effects. It has been reported that the basic requirements for the use of LAB strains as probiotics include the following: (1) they should be generally recognized as safe (GRAS); (2) they should be tolerant to acid and bile; (3) they should be able to adhere to the intestinal epithelium of the hosts; (4) they should be able to demonstrate antagonistic activity against pathogenic bacteria; and (5) they 
should be able to retain their viability during processing and storage (Lin et al., 2006; Lonkar et al., 2005; Rial, 2000).

The aim of this study was to isolate and screen a specific $\mathrm{LAB}$ with potentially significant anti-obesity activity with a view to applying it to functional food products.

\section{Materials and Methods}

\section{Isolation of lactic acid bacteria}

The strain Q180 was isolated from the feces of healthy adults in a modified MRS medium (Lim et al., 2011). The strain was incubated in Lactobacilli MRS broth (Difco, USA) as the growth medium at $37^{\circ} \mathrm{C}$ for $18 \mathrm{~h}$.

\section{Identification of strain Q180}

The properties of the strain Q180 were investigated by testing the Gram staining and microscopic observation after cultivation on MRS broth for $18 \mathrm{~h}$ at $37^{\circ} \mathrm{C}$. Bergey's Manual of Systematic Bacteriology by Buchanan and Gibbons (1974) was used to examine the morphological and physiological properties of the isolated strains. The Q180 strain was identified by using the $16 \mathrm{~S}$ rDNA sequencing method. The chromosomal DNA of the isolated strain was separated by using a SolGent Genomic DNA prep kit (SolGent, Korea). The DNA extracts were used for the polymerase chain reaction (PCR) with universal primers [27F (5'-AGA GTT TGA TCC TGG CTC AG-3') and 14 92R (5'-GGT TAC CTT GTT ACG ACT T-3')]. PCR was carried out in a programmable therma cycler (SolGent EF-Taq, Korea), according to the following steps: one cycle of denaturation at $95^{\circ} \mathrm{C}$ for $15 \mathrm{~min}$, followed by 30 cycles of $95^{\circ} \mathrm{C}$ for $20 \mathrm{~s}, 50^{\circ} \mathrm{C}$ for $40 \mathrm{~s}$, and $72^{\circ} \mathrm{C}$ for $90 \mathrm{~s}$. The final extension was carried out at $72^{\circ} \mathrm{C}$ for $5 \mathrm{~min}$. The purified PCR product obtained by using a SolGent PCR purification kit (SolGent, Korea) was used for sequencing with an ABI 3730XL DNA analyzer (Applied Biosystems, USA).

\section{Lipase activity}

The method of Lee et al. (1993) for lipase activity determination was modified. The pancreatic lipase activity was measured using porcine pancreatic lipase (Sigma, USA). $0.1 \mathrm{mg} / \mathrm{mL}$ of a sample solution dissolved in water, and $0.167 \mathrm{mM} p$-Nitrophenylpalmitate (PNP; Sigma, USA) solution and $0.061 \mathrm{M}(\mathrm{pH}$ 8.5) Tris-HCl buffer were mixed in the well of a plate, and $0.3 \mathrm{mg} / \mathrm{mL}$ of the lipase solution was then added to start the enzyme reaction. After incubation at $25^{\circ} \mathrm{C}$ for $10 \mathrm{~min}$, its absorbance was measured at $405 \mathrm{~nm}$.

\section{Cell line and cell culture}

3T3-L1 cells were obtained from the American Type Culture Collection (ATCC, USA) and were cultured at $37^{\circ} \mathrm{C}$ in humidified $5 \% \mathrm{CO}_{2}$ atmosphere. 3T3-L1 cells were cultured as described by Hemati et al. (1997). Briefly, the cells were grown in Dulbecco's modified Eagle's medium (DMEM, GIBCO, USA) containing high glucose supplemented with $10 \%$ bovine calf serum (BCS, GIBCO, USA) and $1 \%$ penicillin/streptomycin in six well culture plates. Two days later, confluence cells were cultured in an adipocyte differentiation cocktail medium containing $0.5 \mathrm{mM}$ 3-isobutyl-1-methylxanthine (IBMX, Sigma, USA), $1 \mathrm{M}$ dexamethasone (Dex, Sigma, USA), and $5 \mathrm{~g} / \mathrm{mL}$ insulin (Sigma, USA) in DMEM supplemented with $10 \%$ fetal bovine serum (FBS, GIBCO, USA) for $2 \mathrm{~d}$. The differentiation was complete after $6 \mathrm{~d}$.

\section{Sample preparation and Treatment of $L$. plantarum Q180}

L. plantarum $\mathrm{Q} 180$ was incubated at $37^{\circ} \mathrm{C}$ for $18 \mathrm{~h}$ in MRS broth. All of the purified strains were kept at $70^{\circ} \mathrm{C}$ until use. After culturing L. plantarum Q180, all of the strains were harvested in a refrigerated centrifuge $(1,500 \mathrm{~g}$ for $15 \mathrm{~min}$ at $4^{\circ} \mathrm{C}$ ) and washed three times with distilled water to remove any remaining MRS broth. The washed L. plantarum Q180 was freeze-dried and re-suspended in distilled water at a concentration of $10 \mathrm{mg} / \mathrm{mL}$ and homogenized for $50 \mathrm{sec}$ followed by $1 \mathrm{~min}$ of rest (repeated 3 times) using a sonicator. The 3T3-L1 cells were treated with three different concentrations of supernatant, i.e., 0 $\mathrm{g} / \mathrm{mL}$ (control), $10 \mathrm{~g} / \mathrm{mL}$, and $100 \mathrm{~g} / \mathrm{mL}$.

\section{Oil Red O staining of 3T3-L1 adipocytes}

Intracellular lipid accumulation was measured using oil red O (Sigma, USA). Oil red O straining of 3T3-L1 cells was done using a modified version of the method described by Ramirez-Zacarias et al. (1992). 3T3-L1 cells were washed with PBS twice, fixed with $10 \%$ formaldehyde/ PBS at $4^{\circ} \mathrm{C}$ for $1 \mathrm{~h}$ and stained with filtered oil red $\mathrm{O}$ solution (stock solution: $3.5 \mathrm{mg} / \mathrm{mL}$ in isopropanol; working solution: $60 \%$ oil red $\mathrm{O}$ stock solution and $40 \%$ distilled water) at room temperature for $30 \mathrm{~min}$. The quantification of lipid accumulation was achieved by oil red $\mathrm{O}$ obtained from stained cells with isopropyl alcohol and measured spectro-photometrically at $520 \mathrm{~nm}$. The material stained with oil red $\mathrm{O}$ was expressed on a per cell basis using the cell number determined from similar plates. The 
percentage of the material stained with oil red $\mathrm{O}$ relative to the control wells containing the cell culture medium without compounds was calculated as $520 \mathrm{~nm}$ (Q180)/ $520 \mathrm{~nm}$ (control) $\times 100$.

\section{Growth of strain}

The number of viable $L$. plantarum Q180 was determined by serial ten-fold dilution in $0.1 \%$ peptone water. $50 \mathrm{~L}\left(9.6 \times 10^{5} / \mathrm{mL}\right)$ of L. plantarum Q180 was inoculated into $150 \mathrm{~mL}$ of $10 \%$ reconstituted skimmed milk, and then the culture was incubated at $3 \mathrm{~h}$ intervals for $24 \mathrm{~h}$ at $34^{\circ} \mathrm{C}, 37^{\circ} \mathrm{C}$ and $40^{\circ} \mathrm{C}$. All pour plates were incubated aerobically at $37^{\circ} \mathrm{C}$ for $48 \mathrm{~h}$ using a $\mathrm{BCP}$ plate count agar (Eiken, Japan).

\section{Antibiotic tolerance}

L. plantarum Q180 was grown at $37^{\circ} \mathrm{C}$ for $18 \mathrm{~h}$ in MRS broth and inoculated $(1 \%, \mathrm{v} / \mathrm{v})$ into a MRS broth supplemented with antibiotics (amikacin, gentamicin, kanamycin, neomycin, streptomycin, penicillin-G, methicillin, oxacillin, ampicillin, bacitracin, rifampicin, novobiocin, lincomycin, polymyxin B and chloramphenico, Sigma, USA) at various concentrations in a two-fold dilution step. The minimal inhibitory concentration (MIC) was determined by checking the moment at which the strain stopped growing after incubation at $37^{\circ} \mathrm{C}$ for $48 \mathrm{~h}$.

\section{Enzyme activity}

An API ZYM kit (bioMerieux, Lyon, France) was used to study enzyme activity. L. plantarum Q180 was grown at $37^{\circ} \mathrm{C}$ for $18 \mathrm{~h}$ in MRS broth. Sediment from the centrifuged broth culture was used to prepare the suspension at $10^{5}-10^{6} \mathrm{CFU} / \mathrm{mL}$. After inoculation, the cultures were incubated for $5 \mathrm{~h}$ at $37^{\circ} \mathrm{C}$. The addition of a surface active agent (ZYM A reagent) in the cupules facilitated the solubilization of the ZYM B reagent in the medium. Color was allowed to develop for at least $5 \mathrm{~min}$, and values ranging from 0-5 (corresponding to the colors developed) were assigned. The approximate number for the free nmol hydrolyzed substrate was determined based on the color strength: 0 , negative reaction; $1,5 \mathrm{nmol} ; 2,10 \mathrm{nmol} ; 3$, $20 \mathrm{nmol}$; 4, $30 \mathrm{nmol}$; 5, $40 \mathrm{nmol}$ or higher.

\section{Bile tolerance}

Bile tolerance was tested as described by Gilliland and Walker (1990). L. plantarum Q180 was grown at $37^{\circ} \mathrm{C}$ for $18 \mathrm{~h}$ in MRS broth. Each 1\% of the L. plantarum Q180 strain culture was inoculated into sterilized MRS broth containing $0.05 \%$ L-cysteine (Sigma, USA) with or without $0.3 \%$ oxgall (Sigma, USA), and then the growth potential was compared in the presence of the bile. Then, the cultures were incubated anaerobically at $1 \mathrm{~h}$ intervals for $7 \mathrm{~h}$ at $37^{\circ} \mathrm{C}$. All pour plates were incubated anaerobically at $37^{\circ} \mathrm{C}$ for $48 \mathrm{~h}$ using the BCP plate count agar.

\section{Acid tolerance}

Acid tolerance was tested as described by Clark et al. (1993). Solutions of $37 \% \mathrm{HCl}$ in double-distilled water were adjusted to $\mathrm{pH}$ levels of 2.0, 3.0, and 4.0. Sterile double-distilled water $(\mathrm{pH}$ 6.4) served as the control. 10 $\mathrm{mL}$ of each $\mathrm{pH}$ solution was transferred into sterile test tubes. $1 \mathrm{~mL}$ of stock culture containing approximately $10^{9}$ CFU/mL of L. plantarum Q180 using MRS agar containing $0.05 \%$ cysteine was then transferred into each of the four $\mathrm{pH}$ solutions. The $\mathrm{pH}$ solutions containing L. plantarum Q180 were then incubated anaerobically at $37^{\circ} \mathrm{C}$, followed by intermittent plating after 1,2 , and $3 \mathrm{~h}$ to stimulate the survival of L. plantarum Q180 under $\mathrm{pH}$ conditions common to the human stomach. Samples from the $\mathrm{pH}$ solution were re-suspended and subjected to serial dilutions. About $100 \mu \mathrm{L}$ of the abovementioned sample solution was spread onto the surface of the BCP plate count agar plates and incubated anaerobically at $37^{\circ} \mathrm{C}$ for $48 \mathrm{~h}$.

\section{Antimicrobial activity}

Antimicrobial activity was tested as described by Gilliland and Speck (1977). Escherichia coli KFRI 174, Salmonella Typhimurium KFRI 250, and Staphylococcus aureus KFRI 219 were obtained from the culture collection of the Korea Food Research Institute (Sungnam, Korea). Escherichia coli was enumerated on EMB agar (Difco, USA), Salmonella Typhimurium on Bismuth sulfite agar (Difco, USA), and Staphylococcus aureus on Baird Parker agar (Difco, USA). All the plates were incubated for $48 \mathrm{~h}$ at $37^{\circ} \mathrm{C}$. Both the control culture and the associative culture were incubated for $6 \mathrm{~h}$ at $37^{\circ} \mathrm{C}$. At the end of the incubation period, the samples were removed and placed in an ice bath until analysis. The number of CFU of pathogens per $\mathrm{mL}$ was determined using the appropriate selective medium. Percentages of inhibition were determined using the following formula:

Inhibition $(\%)=$

$\underline{(\mathrm{CFU} / \mathrm{mL} \text { in control })-(\mathrm{CFU} / \mathrm{mL} \text { in associative culture })} \times 100$ $(\mathrm{CFU} / \mathrm{mL}$ in control) 


\section{Statistical analysis}

The results are expressed as the mean \pm standard deviation (SD). The statistical analysis was performed with a statistical analysis system (SAS, SAS Institute Inc., USA). The significance of the differences was analyzed by conducting a one-way analysis of variance (ANOVA) with Duncan's multiple range tests. Values of $p<0.05$ were considered statistically significant.

\section{Results and Discussion}

\section{Isolation of lactic acid bacteria}

The feces samples were collected from healthy adult staff members of the Korea Food Research Institute (Sungnam, Korea), and 188 strains were isolated as lactic acid bacteria in a modified MRS medium. The strain was incubated in lactobacilli MRS broth as the growth medium at $37^{\circ} \mathrm{C}$ for $18 \mathrm{~h}$.

\section{Selection of strain of anti-obesity activity}

Several approaches to the prevention and treatment of obesity have been reported (Birari et al., 2007). Among these, both natural and synthetic pancreatic lipase inhibitors are effective in preventing obesity, which is likely to be due to their inhibition of intestinal lipid absorption (Hirose et al., 2013). After being incubated in MRS broth at $37^{\circ} \mathrm{C}$ for $18 \mathrm{~h}$, three kinds of strains having a lipase inhibitory activity of over $60 \%$ were selected from among the 188 strains by measuring their lipase inhibitory activity. Table 1 showed that then Q180 strain exhibited the highest lipase inhibitory activity among the three selected strains. The Q180 strain exhibited a lipase inhibitory activity of $83.61 \pm 2.31 \%$ compared with the control. Fig. 1 showed that an 8-day treatment at various concentrations $[0-100 \mu \mathrm{g} / \mathrm{mL}]$ of the Q180 strain during the differentiation period significantly and dose-dependently inhibited 3T3-L1 adipogenesis in terms of lipid accumulation compared with the control cells. Among the tested concentrations of Q180, $100 \mu \mathrm{g} / \mathrm{mL}$ was the most effective at reducing the lipid content in differentiated cells (by $14.63 \pm$ $1.37 \%$ compared with the control cells). These results suggest that Q180 inhibits pancreatic lipase (PL) and the differentiation of 3T3-L1 preadipocytes by suppressing lipid accumulation.

\section{Identification and DNA sequencing of the selected Q180 strain}

Physiological and biochemical tests were conducted to determine the genus and species of the selected Q180
Table 1. Anti-lipase activity of selected lactic acid bacteria

\begin{tabular}{ccc}
\hline Strains & Anti-lipase activity (\%) & Source \\
\hline F22 & $68.01 \pm 0.86$ & Feces of adults \\
Q180 & $83.61 \pm 2.32$ & Feces of adults \\
Q185 & $70.90 \pm 0.55$ & Feces of adults \\
\hline
\end{tabular}

All values are mean \pm standard deviation of three replicates.

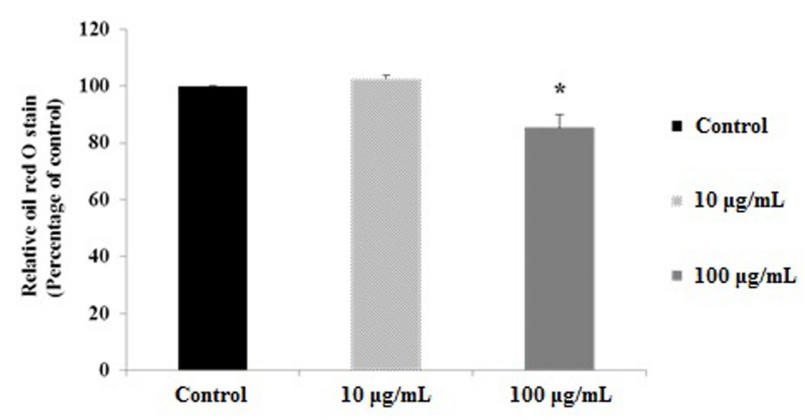

(B)

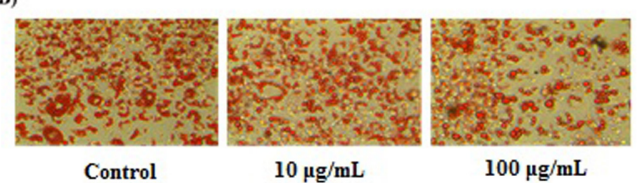

Fig. 1. The effects of L.plantarum Q180 on oil red $O$ stained in 3T3-L1 adipocyte: (A) quantification of oil red $\mathrm{O}$ staining * significant difference from control at $p<0.05$; (B) photograph of oil red $\mathrm{O}$ staining. Cells were stained with oil red $\mathrm{O}$ observed by using a microscope (original magnification $\times 200$ ).

strain. The Q180 strain consisted of non-spore, rod-type, gram-positive bacteria and exhibited negative properties on catalase and motility. In addition, it cannot grow at $15^{\circ} \mathrm{C}$ and $45^{\circ} \mathrm{C}$. As it does not produce gas and ammonia from glucose and arginine, it has been identified as a genus Lactobacillus (Table 2). After PCR amplification using universal primers targeting $16 \mathrm{~S}$ rDNA and the following sequence analysis, it was identified as Lactobacillus plantarum with a similarity of $99 \%$ (data not shown). Based on the results of previous studies, it was named $L$. plantarum Q180.

\section{Growth of strain}

The number of viable $L$. plantarum Q180 was determined by serial ten-fold dilution in $0.1 \%$ peptone water. $10 \mu \mathrm{L}\left(9.6 \times 10^{5} / \mathrm{mL}\right)$ of L. plantarum Q180 was inoculated into $150 \mathrm{~mL}$ of $10 \%$ reconstituted skimmed milk, and then the culture was incubated at $34^{\circ} \mathrm{C}, 37^{\circ} \mathrm{C}$ and $40^{\circ} \mathrm{C}$ for $24 \mathrm{~h}$, and checked at intervals of $3 \mathrm{~h}$, with the highest growth rate identified at $37^{\circ} \mathrm{C}$. The optimum growth temperature of $L$. plantarum Q180 was found to 
Table 2. Physiological characteristics of Lactobacillus plantarum Q180

\begin{tabular}{|c|c|c|c|}
\hline Gram reaction & & + & \\
\hline Cell type & & rod & \\
\hline Spore forming & & - & \\
\hline Motility & & - & \\
\hline Aerobic growth & & + & \\
\hline Anaerobic growth & & + & \\
\hline Catalase reaction & & - & \\
\hline Growth at $15^{\circ} \mathrm{C}$ & & - & \\
\hline Growth at $45^{\circ} \mathrm{C}$ & & - & \\
\hline Gas forming from glucose & & - & \\
\hline $\begin{array}{l}\text { Ammonia production } \\
\text { from alginin }\end{array}$ & & - & \\
\hline Acid production from & & & \\
\hline Glycerol & - & Salicin & + \\
\hline Erythritol & - & D-Celiobiose & + \\
\hline D-Arabinose & - & D-Maltose & + \\
\hline L-Arabinose & + & D-Lactose & + \\
\hline D-Ribose & + & D-Melibiose & + \\
\hline D-Xylose & - & D-Saccharose & + \\
\hline L-Xylose & - & D-Trehalose & + \\
\hline D-Adonitol & - & Inulin & - \\
\hline 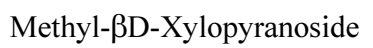 & - & D-Melezitose & + \\
\hline D-Galactose & + & D-Raffinose & + \\
\hline D-Glucose & + & Amidon (starch) & - \\
\hline D-Fructose & + & Glycogen & - \\
\hline D-Mannose & + & Xylitol & - \\
\hline L-Sorbose & - & Gentiobiose & + \\
\hline L-Rhamnose & + & D-Turanose & + \\
\hline Dulcitol & - & D-Lyxose & - \\
\hline Inositol & - & D-Tagatose & - \\
\hline D-Mannitol & + & D-Fucose & - \\
\hline D-Sorbitol & - & L-Fucose & - \\
\hline $\begin{array}{c}\text { Methyl-aD- } \\
\text { Mannopyranoside }\end{array}$ & + & D-Arabitol & + \\
\hline Methyl-aD-Glucopyranoside & - & L-Arabitol & - \\
\hline N-AcetylGlucosamine & + & Potassium Gluconate & + \\
\hline Amygdalin & + & Potassium 2-KetoGluconate & - \\
\hline Arbutin & + & Potassium 5-KetoGluconate & - \\
\hline Esculin & + & & \\
\hline
\end{tabular}

be $37^{\circ} \mathrm{C}$ (Fig. 2).

\section{Antibiotic tolerance}

When using lactic acid bacteria as probiotics, the ability to survive in antibiotic circumstances is an essential factor (Havinaar et al., 1992). Table 3 shows the tolerance of the L. plantarum Q180 strain to sixteen kinds of antibiotics. The results showed that the L. plantarum Q180 strains were susceptible to Gram-positive spectrum antibiotics (bacitracin, novobiocin, lincomycin). In fact, L. plantarum Q180 showed itself to be more sensitive to novobiocin in a comparison of fifteen different antibiotics, and exhib-
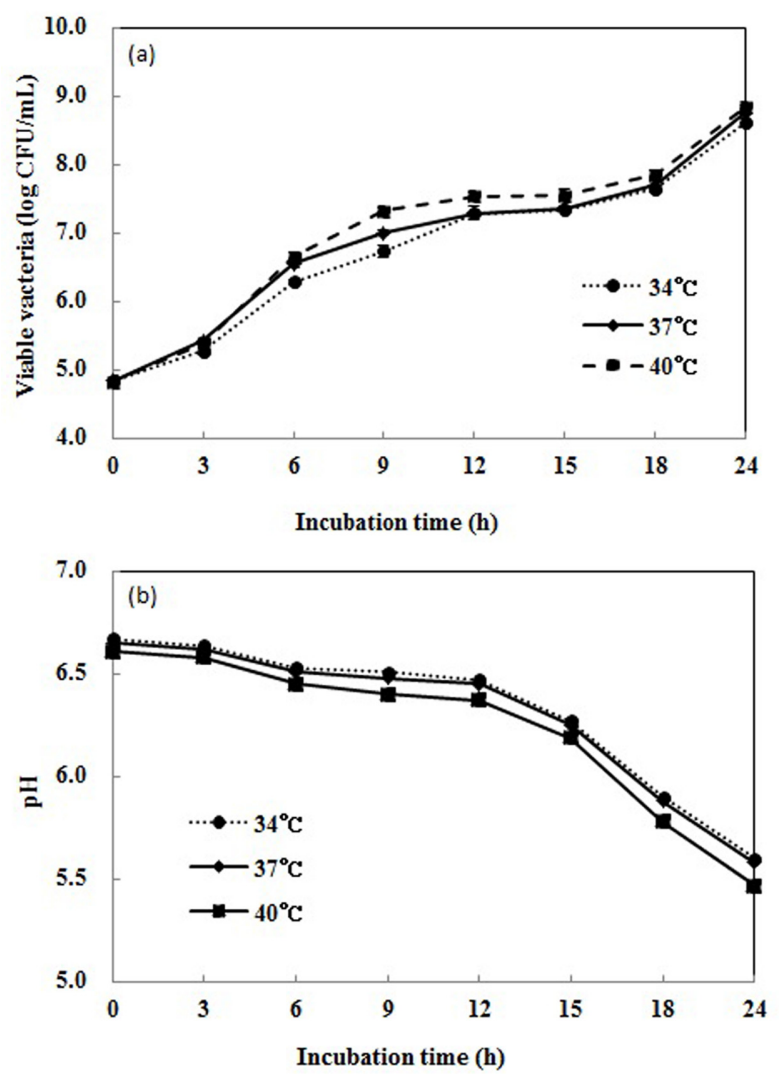

Fig. 2. Growth curve (a), and pH changes (b) of Lactobacillus plantarum Q180 in MRS broth at various temperatures. (a) All values are within the mean \pm standard deviation of the three replicates.

ited the greatst resistance to rifampicin, polymyxin B and vancomycin. Among antibiotic resistances, vancomycin resistance is of major concern because vancomycin is one of the last antibiotics to remain broadly efficacious against clinical infections caused by multidrug-resistant pathogens (Zhou et al., 2005). Some LABs including strains of L. rhamnosus, L. casei, L. plantarum, Leuconostoc spp. and pediococci are resistant to vancomycin. Such resistance is usually intrinsic, it is chromosomally encoded and nontransmissible (Handwerger et al., 1994; Klein et al., 1998; Ruoff et al., 1988; Swenson et al., 1990). These results show that the L. plantarum Q180 strain generally showed slightly higher susceptibility against antibiotics.

\section{Enzyme activity}

Enzyme activity is also important when using lactic acid bacteria as probiotics. Probiotics should not produce $\beta$ glucuronidase, a toxic enzyme which has been implicated in the formation of carcinogens (Borriello et al., 2003). When carcinogenic substances such as benzo(a)pyrene enter the human body, their poisonous effects are counter- 
Table 3. Antibiotics susceptibility of Lactobacillus plantarum Q180

\begin{tabular}{lc}
\hline \hline $\begin{array}{c}\text { Antimicrobal } \\
\text { agents }\end{array}$ & $\begin{array}{c}\text { minimal inhibitory concentrations } \\
(\mu \mathrm{g} / \mathrm{mL})\end{array}$ \\
\hline Aminoglycosides & $40 \pm 0$ \\
Amikacin & $10 \pm 0$ \\
Gentamycin & $100 \pm 0$ \\
Kanamycin & $25 \pm 0$ \\
Neomycin* & $200 \pm 0$ \\
Streptomycin & $10 \pm 0$ \\
\hline -lactams & $40 \pm 0$ \\
Penicillin-G* & $30 \pm 0$ \\
Methicillin & $120 \pm 0$ \\
Oxacillin & $15 \pm 0$ \\
Ampicillin & $960 \pm 0$ \\
\hline Gram-positive spectrum & $7.5 \pm 0$ \\
Bacitracin* & $12.5 \pm 0$ \\
Rifampicin & \\
Novobiocin & $1200 \pm 0$ \\
Lincomycin* & $40 \pm 0$ \\
\hline Gram-negative spectrum & $1600 \pm 0$ \\
Polymyxin B* & \\
\hline Broad spectrum & \\
Chloramphenicol & Vancomycin
\end{tabular}

*units/mL

All values are the mean \pm standard deviation of three replicates.

acted due to conjugation with glucuronic acid in the liver. If this conjugated product is excreted with bile acid in the intestine, cleavage $\beta$-glucuronidase can liberate these substances to become toxic once again. On the other hand, enzymes such as lipase, protease, and $\beta$-galactosidase have advantages for digestion and the treatment of lactose intolerance (Kumar et al., 2012). L. plantarum Q180 did not produce $\beta$-glucuronidase; rather, it produced such enzymes as leucine arylamidase, naphtol-AS-BI-phosphohydrolase, $\beta$-galactosidase, $\alpha$-glucosidase, $\mathrm{N}$-acetyl- $\beta$-glucosaminidase, and $\alpha$-mannosidase. Notably, the activities of $\beta$-galactosidase and $\mathrm{N}$-acetyl- $\beta$-glucosaminidase were 4 degree (Table 4). According to Lee et al. (2006), L. plantarum NK181 isolated from jeotgal produced such enzymes as leucine arylamidase, valine acrylamides, acid phosphatase, naphtol-AS-BI-phosphohydrolase, $\beta$-galactosidase, $\alpha, \beta$-glucosidase, and $\mathrm{N}$-acetyl- $\beta$-glucosaminidase. This result shows that the enzyme profiles of the L. plantarum Q180 strain were similar to those of L. plantarum NK181.

\section{Bile tolerance}

Resistance to human gastric transit constitutes an essential evaluation criterion for probiotic bacteria (Goldin et
Table 4. Enzyme patterns of Lactobacillus plantarum Q180

\begin{tabular}{cc}
\hline \hline Enzyme & L. plantarum Q180 \\
\hline Alkaline phosphatase & 1 \\
Esterase (C4) & 2 \\
Esterase Lipase (C8) & 2 \\
Lipase (C14) & 1 \\
Leucine arylamidase & 3 \\
Valine arylamidase & 2 \\
Cystinearylamidase & 2 \\
Trypsin & 1 \\
$\alpha$-chymotrypsin & 1 \\
Acid phosphatase & 1 \\
$\alpha$-galactosidase & 3 \\
$\beta$-galactosidase & 2 \\
$\beta$-glucuronidase & 4 \\
$\alpha$-glucosidase & 1 \\
$\beta$-glucosidase & 3 \\
$\alpha$-acetyl- $\beta$-glucosaminidase & 1 \\
$\alpha$-fucosidase & 4 \\
\hline
\end{tabular}

*A value ranging from 0 to 2 is assigned to the standard color: zero represents a negative; 5 represents a reaction of maximum intensity. Values 1 through 4 represent intermediate reactions depending on the level of intensity. The approximate activity may be estimated from the color strength: 1 corresponds to the liberation of 5 nanomoles, 2 to 10 nanomoles, 3 to 20 nanomoles, 4 to 30 nanomoles, and 5 to 40 nanomoles or more.

al., 1989; Klaenhammer et al., 1982). Moreover, bile salt tolerance is considered one of the necessary properties required for lactic acid bacteria to survive in the small intestine (Park et al., 1998; Saarela et al., 2000). Bile secreted in the small intestine reduces the survival of bacteria by destroying their cell membranes, whose major components are lipids and fatty acids, and these modifications may affect not only cell permeability and viability, but also the interactions between the membrane and the environment (Gilliland et al., 1984). Fig. 3 shows the growth curves in MRS broth or MRS broth containing $0.3 \%$ bile. A $0.3 \%$ concentration of bile salt is considered the critical screen for probiotics in the human gastrointestinal tract (Gilliland et al., 1984). The log value of the population after incubation for $7 \mathrm{~h}$ without $0.3 \%$ oxgall was 8.9 , but it was 8.7 with the addition of $0.3 \%$ bile. Therefore, the survival rate of $L$. plantarum Q180 in MRS broth containing $0.3 \%$ bile was $97.8 \%$. L. plantarum Q180 has probiotic potential because a comparatively high percentage of the strain survived in MRS broth containing $0.3 \%$ bile salt.

\section{Acid tolerance}

Therefore, before a probiotic can benefit human health, 


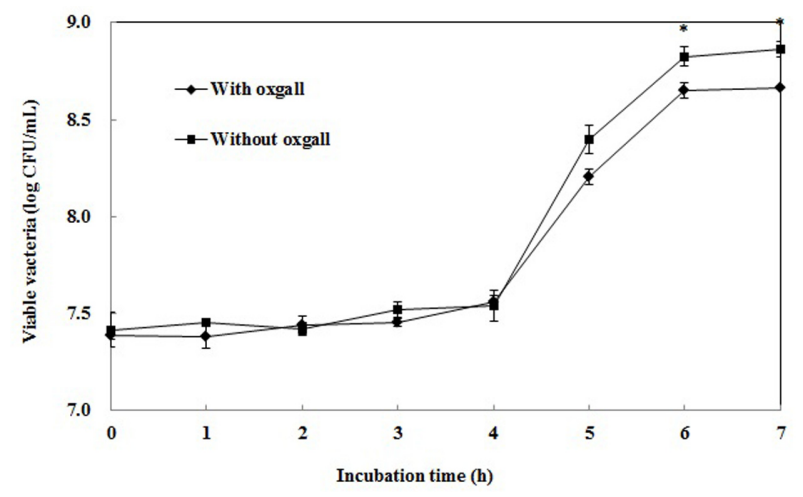

Fig. 3. Growth of Lactobacillus plantarum Q180 in MRS broth containing $0.05 \%$ L-cysteine with/without $0.3 \%$ oxgall. ${ }^{*} p<0.05$ between oxgall and without oxgall $(t$-test).

it must satisfy several criteria such as the ability to tolerate acid and to grow in the lower intestinal tract (Hirayama et al., 2000; Ouwehand et al., 2002; Pereira et al., 2002; Zhu et al., 2000). To be a good probiotic, it is necessary to survive in a $\mathrm{pH}$ lower than 3 so that it can reach the small intestine via the stomach (Booth, 1985; McDonald et al., 1990). Fig. 4 shows the $\mathrm{pH}$ tolerance of L. plantarum Q180. It showed a 97.2\% survival rate after incubation for $3 \mathrm{~h}$ in highly acidic conditions ( $\mathrm{pH} 2.0)$. Lim and $\operatorname{Im}$ (2009) reported that L. plantarum isolated from kimchi was resistant in acidic condition, showing a $98.8 \%$ survival rate after incubation for $2 \mathrm{~h}$ at $\mathrm{pH} 2.5$. Pennacchia et al. (2004) reported a $60-80 \%$ survival rate for $\mathrm{LAB}$ incubated in a PBS buffer at $\mathrm{pH} 2.5$ for $3 \mathrm{~h}$ at $37^{\circ} \mathrm{C}$.

\section{Antimicrobial activity}

Antagonism against pathogens is one of the main criteria for selecting probiotics (Ouwehand et al., 2002). The antagonistic activities demonstrated by lactic acid bacteria may be due to the production of substances with antibacterial properties in particular: hydrogen peroxide, organic acid and bacteriocins (Tejero-Sarimena et al., 2012). According to previous studies, Lactobacillus strains show a variable ability to inhibit pathogens even within a same species (Jacobsen et al., 1999; Larsen et al., 1993; Stra-

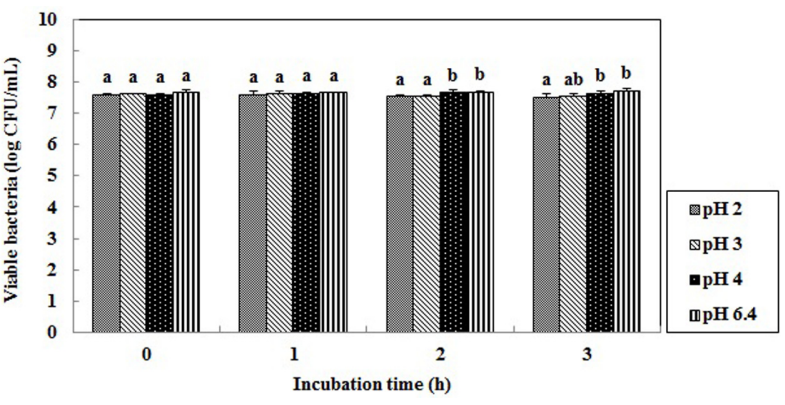

Fig. 4. Survival of Lactobacillus plantarum Q180 after $3 \mathrm{~h}$ in HCl solution (pH 2.0, 3.0, 4.0 and 6.4). ${ }^{\mathrm{a}-\mathrm{b}}$ Means values with different superscript within same time are significantly different $(p<0.05)$.

hinic et al., 2007).

Table 5 shows the antimicrobial activity of $L$. plantarum Q180 against various pathogenic strains. L. plantarum Q 180 showed resistance against $E$. coli, $S$. Typhimurium and S. aureus at rates of $55.6 \%, 38.0 \%$, and $47.6 \%$, respectively. The $\mathrm{pH}$ value of pathogens after incubation for $7 \mathrm{~h}$ was 6.4 , but the $\mathrm{pH}$ value of a mixed culture with $L$. plantarum Q180 and pathogens was around 5.5-5.6. It means that even lactic acid produced during incubation affected on antimicrobial activity, it is not large effect.

\section{Conclusion}

We investigated whether lactic acid bacteria isolated from the feces of healthy adults exhibit any anti-obesity activity such as a pancreatic lipase (PL) inhibitory activity, inhibition of adipocyte differentiation of 3T3-L1 cells. The selected Q180 strain was identified as L. plantarum as a result of the API carbohydrate fermentation test and $16 \mathrm{~S}$ rDNA sequence. The optimum growth temperature of Q180 was $37^{\circ} \mathrm{C}$. L. plantarum Q180 could survive in antibiotic conditions at a low concentration and did not produce carcinogenic enzymes such as $\beta$-glucuronidase. Moreover, it was found to be comparatively tolerant to bile juice and acid, and displayed resistance to pathogenic strains. These results demonstrate that L. plantarum Q180

Table 5. Inhibition of pathogens by Lactobacillus plantarum Q180 in MRS broth

\begin{tabular}{cccccc}
\hline \hline \multirow{2}{*}{ Pathogens } & \multicolumn{2}{c}{ Pathogens $^{\mathrm{a}}$} & \multicolumn{2}{c}{ L. plantarum Q180 $^{\mathrm{a}}+$ Pathogens } & \multirow{2}{*}{ Inhibition (\%) } \\
\cline { 2 - 5 } & $\mathrm{CFU} / \mathrm{mL}$ & $\mathrm{pH}$ & $\mathrm{CFU} / \mathrm{mL}$ & $\mathrm{pH}$ & 56.5 \\
Escherichia coli & $2.0 \pm 0.4 \times 10^{8}$ & 6.4 & $8.7 \pm 0.3 \times 10^{7}$ & 5.6 & 34.7 \\
Salmonella Typhimurium & $7.2 \pm 0.3 \times 10^{6}$ & 6.4 & $4.7 \pm 0.2 \times 10^{6}$ & 5.5 & 48.5 \\
Staphylococcus aureus & $3.3 \pm 0.5 \times 10^{8}$ & 6.4 & $1.7 \pm 0.3 \times 10^{8}$ & 5.5 & \\
\hline
\end{tabular}

*Initial count of L. plantrum Q180: $3.6 \pm 0.5 \times 10^{6} \mathrm{CFU} / \mathrm{mL}$

${ }^{\text {a }}$ Determined after $6 \mathrm{~h}$ of incubation at $37^{\circ} \mathrm{C}$

All values are the mean \pm standard deviation of three replicates. 
could be an excellent strain for anti-obesity activity.

\section{Acknowledgements}

The study was financially supported by Technology Development Program for Agriculture and Forestry Ministry for Food, Agriculture, Forestry and Fisheries, 2013.

\section{References}

1. Aihara, K., Kajimoto, O., Hirata, H., Takahashi, R., and Nakamura, Y. (2005) Effect of powdered fermented milk with Lactobacillus helveticus on subjects with high-normal blood pressure or mild hypertension. J. Am. Coll. Nutr. 24, 257-265.

2. Baken, K. A., Ezendam, J., Gremmer, E. R., de Klerk, A., Pennings, J. L., Matthee, B., Peijnenburg, A. A., and van Loveren, H. (2006) Evaluation of immunomodulation by Lactobacillus casei Shirota: immune function, autoimmunity and gene expression. Int. J. Food. Microbiol. 112, 8-18.

3. Birari, R. B. and Bhutani, K. K. (2007) Pancreatic lipase inhibitors from natural sources: unexplored potential. Drug Discov. Today 12, 879-889.

4. Booth, I. R. (1985) Regulation of cytoplasmic $\mathrm{pH}$ in bacteria. Microbiol. Rev. 49, 359-378.

5. Borriello, S. P., Hammes, W. P., Holzapfel, W., Marteau, P., Schrezenmeir, J., Vaara, M., and Valtonen, V. (2003) Safety of probiotics that contain lactobacilli or bifidobacteria. Clin. Infect. Dis. 36, 775-780.

6. Buchanan, R. E. and Gibbons, N. E. (1974) Bergey's manual of determinative bacteriology. (ed), Waverly Press, Inc., Baltimore, pp. 576-593.

7. Clark, P. A., Cotton, L. N., and Martin, J. H. (1993) Selection of bifidobacteria for use as dietary adjuncts in cultured dairy foods: II-tolerance to simulated $\mathrm{pH}$ of human stomachs. $\mathrm{Cul}$. Dairy Prod. J. 28, 11-14.

8. Gilliland, S. E. and Speck, M. L. (1977) Antagonistic action of Lactobacillus acidophilus toward intestinal and foodborne pathogens in associative cultures. J. Food Prot. 40, 820-823.

9. Gilliland, S. E., Staley, T. E., and Bush, L. J. (1984) Importance of bile tolerance of Lactobacillus acidophilus used as a dietary adjunct. J. Dairy Sci. 67, 3045-3051.

10. Gilliland, S. E. and Walker, D. K. (1990) Factors to consider when selecting a culture of Lactobacillus acidophilus as a dietary adjunct to produce a hypocholesterolemic effect in humans. J. Dairy Sci. 73, 905-911.

11. Glenny, A. M., OMeara, S., Melville, A., Sheldon, T. A., and Wilson, C. (1997) The treatment and prevention of obesity; a systematic review of the literature. Int. J. Obes. 21, 715-737.

12. Goldin, B. R. and Gorbach, S. L. (1989) Lactobacillus strain and methods of selection, US Patent 4,839,281.

13. Handwerge, S., Pucci, M. J., Volk, K. J., Liu, J. P., and Lee, M. S. (1994) Vancomycin-resistant Leuconostoc mesenteroides and Lactobacillus casei synthesize cytoplasmic peptidoglycan precursors that terminate in lactate. J. Bacteriol. 176, 260-264.
14. Havinaar, R., Brink, B. T., and Veid, J. H. J. I. (1992) Selection of strains for probiotic use. In: Fuller R. (ed), Chapman \& Hall, London, pp. 209-224.

15. Hemati, N., Ross, S. E., Erickson, R. L, Groblewski, G. E., and MacDuygald, O. A. (1997) Signaling pathways through which insulin regulates CCAAT/enhancer binding protein-á $(\mathrm{C} / \mathrm{EBP}-\alpha)$ phosphorylation and gene expression in 3T3-L1 adipocytes. Forrelation with CLUT4 gene expression. J. Biol. Chem. 272, 25913-25919.

16. Hirayama, K. and Rafter, J. (2000) The role of probiotic bacteria in cancer prevention. Microbes Infect. 2, 681-686.

17. Hirose, M., Ando, T., Shofiqur, R., Umeda, K., Kodama, Y., Nguyen, S. V., and Goto, T. (2013) Anti-obesity activity of hen egg anti-lipase immunoglobulin yolk, a novel pancreatic lipase Inhibitor. Nutr. Metab. 10, 70-75.

18. Jacobsen, C. N., Nielsen, V. R., Hayford, A. E., Moller, P. L., Michaelsen, K. F., Paerregaard, A., Sandstrom, B., Tvede, M., and Jakobsen, M. (1999) Screening of probiotic activities of forty-seven strains of Lactobacillus spp. by in vitro techniques and evaluation of the colonization ability of five selected strains in humans. Appl. Environ. Microbiol. 65, 4949-4956.

19. Klaenhammer, T. (1982) Microbiological considerations in selection and preparation of Lactobacillus strains for use as dietary adjuncts. J. Dairy Sci. 65, 1339-1345.

20. Klein, G., Pack, A., Bonaparte, C., and Reuter, G. (1998) Taxonomy and physiology of probiotic lactic acid bacteria. Int. J. Food Microbiol. 41, 103-105.

21. Kumar, M., Ghosh, M., and Ganguli, A. (2012) Mitogenic response and probiotic characteristics of lactic acid bacteria isolated from indigenously pickled vegetables and fermented beverages. World. J. Microbiol. Biotechnol. 28, 703-711.

22. Larsen, A. G., Vogensen, F. K., and Josephsen, J. (1993) Antimicrobial activity of lactic acid bacteria isolated from sour doughs: purification and characterization of bavaricin A, a bacteriocin produced by Lactobacillus bavaricus MI401. J. Appl. Bacteriol. 75, 113-122.

23. Lee, N. K., Kim, H. W., Chang, H. I., Yun, C. W., Kim. S. W., Kang, C. W., and Paik, H. D. (2006) Probiotic properties of Lactobacillus plantarum NK181 isolated from Jeotgal, a Korean fermented food. Food Sci. Biotechnol. 15, 227-231.

24. Lee, Y. P., Chung G. H., and Rhee, J. S. (1993) Purification and characterization of Pseudomonas fluorescens SIK W1 lipase expressed in Escherichia coli. Biochim. Biophys. Acta. 1169, 156-164.

25. Lim, S. D., Kim, K. S., and Do, J. R. (2011) Physiological characteristics and production of vitamin $\mathrm{K}_{2}$ by Lactobacillus fermentum LC272 isolated from raw milk. Korean $J$. Food Sci. An. 31, 513-520.

26. Lim, S. M. and Im, D. S. (2009) Screening and characterization of probiotic lactic acid bacteria isolated from Korean fermented foods. J. Microbiol. Biotechnol. 19, 178-186.

27. Lin, W. H., Hwang, C. F., Chen, L. W., and Tsen, H. Y. (2006) Viable counts, characteristic evaluation for commercial lactic acid bacteria products. Food. Microbiol. 23, 74-81.

28. Lonkar, P., Harne, S. D., Kalorey, D. R., and Kurkure, N. V. (2005) Isolation, in vitro antibacteria activity, bacteria sensi- 
tivity and plasmid profile of Lactobacilli. Asian-Australas. $J$. Anim. Sci. 18, 1336-1342.

29. Mcdonald, L. C., Fleming, H. P., and Hassan, H. M. (1990) Acid tolerance of Leuconostoc mesenteroides and Lactobacillus casei. Appl. Environ. Microbial. 53, 2124-2128.

30. Moon, Y. J., Soh, J. R., Yu , J. J., Sohn, H. S., Cha, Y. S., and Oh, S. H. (2012) Intracellular lipid accumulation inhibitory effect of Weissella koreensis OK1-6 isolated from Kimchi on differentiating adipocyte. J. Appl. Microbiol. 113, 652-658.

31. Ouwehand, A. C., Salminen, S., and Isolauri, E. (2002) Probiotics: an overview of beneficial effects. Antonie van Leeuwenhoek. 82, 279-289.

32. Park, D. Y., Ahn, Y. T., Huh, C. S., Jeon, S. M., and Choi, M. S. (2011) The inhibitory effect of Lactobacillus plantarum KY1032 cell extract on the adipogenesis of 3T3-L1 Cells. J. Med. Food. 14, 670-675.

33. Park, H. S., Lee, S. H., and Uhm, T. B. (1998) Selection of microorganisms for probiotics and their characterization. Korean J. Food Nutr. 27, 433-440.

34. Park, Y. H., Kim, J. G., Shin, Y. W., Kim, S. H., and Whang, K. Y. (2007) Effect of dietary inclusion of Lactobacillus acidophilus ATCC 43121 on cholesterol metabolism in rats. $J$. Microbiol. Biotechnol. 17, 655-662.

35. Pennacchia, C., Ercolini, D., Blaiotta, G., Pepe, O., Mauriello, G., and Villani, F. (2004) Selection of Lactobacillus strains from fermented sausages for their potential use as probiotics. Meat Sci. 67, 309-317.

36. Pereira, D. I. and Gibson, G. R. (2002) Effects of consumption of probiotics and prebiotics on serum lipid levels in humans. Crit. Rev. Biochem. Mol. Biol. 37, 259-281.

37. Rafter, J. (2004) The effects of probiotics on colon cancer development. Nutr. Res. Rev. 17, 277-284.

38. Ramirez-Zacarias, J. L., Castro-Munozledo, F., and Kuri-Harcuch, W. (1992) Quantitation of adipose conversion and triglycerides by staining intracytoplasmic lipids with Oil red O.
Histochem. 97, 493-497.

39. Rial, R. D. (2000) The role of probiotic cultures in the control of gastrointestinal health. J. Nutr. 130, 396-402.

40. Ruoff, K. L., Kuritzkes, D. R., Wolfson, J. S., and Ferraro, M. J. (1988) Vancomycin-resistant Gram-positive bacteria isolated from human sources. J. Clin. Microbiol. 26, 2064-2068.

41. Saarela, M., Mogensen, G., Fondén, R., Mättö , J., and Mattila-Sandholm, T. (2000) Probiotic bacteria: safety, functional and technological properties. J. Biotechnol. 84, 197-215.

42. Strahinic, I., Busarcevic, M., Pavlica, D., Milasin, J., Golic, N., and Topisirovic, L. (2007) Molecular and biochemical characterizations of human oral lactobacilli as putative probiotic candidates. Oral Microbiol. Immunol. 22, 111-117.

43. Swenson, J. M., Facklamand, R. R., and Thornsberry, C. (1990) Antimicrobial susceptibility of vancomycin-resistant Leuconostoc, Pediococcus, and Lactobacillus species. Antimicrob. Agents. Chemother. 34, 543-549.

44. Tejero-Sarinena, S., Barlow, J., Costabile, A., Gibson, G. R., and Rowland, J. (2012) In vitro evaluation of the antimicrobial activity of a range of probiotics against pathogens: Evidence for the effects of organic acid. Anaerobe. 18, 530-538.

45. Wickelgren, I. (1998) Obesity; how big a problem? Science 280, 1364-1367.

46. Wood, S. C., Seeley, R. J., Porte, J. D., and Schwarts, M.W. (1998) Signal that regulate food intake and energy homeostasis. Science 280, 1378-1383.

47. Zhou, J. S., Pillidge, C. J., Gopal, P. K., and Gill, H. S. (2005) Antibiotic susceptibility profiles of new probiotic Lactobacillus and Bifidobacterium strains. Int. J. Food Microbiol. 98, 211-217.

48. Zhu, W. M., Liu, W., and Wu, D. Q. (2000) Isolation and characterization of a new bacteriocin from Lactobacillus gasseri KT7. J. Appl. Microbiol. 88, 877-886.

(Received 2014.7.3/Revised 2014.8.30/Accepted 2014.8.30) 